\title{
Comparative efficacy of supplementation of phytoconcentrate herbal preparation and synthetic amino acid on broiler performance
}

\author{
A. B. Kanduri, N. Z. Gaikwad, V. K. Mugale, Shivi Maini ${ }^{1}$ and K. Ravikanth ${ }^{1}$ \\ Department of Animal Nutrition, \\ College of Veterinary and Animal Sciences, \\ Maharashtra Animal and Fisheries Science University, Udgir, Maharashtra, India \\ 1. Research \& Development Centre, Ayurvet Limited, Baddi (H.P.), India \\ * Corresponding author email: shivi@ayurvet.in \\ Received: 16-03-2011, Accepted: 20-04-2011, Published Online: 16-07-2011 \\ doi: $10.5455 /$ vetworld.2011.413-416
}

\begin{abstract}
In view to study the role of herbal sources of essential amino acids in improving growth \& performance, an experiment was conducted on seventy five day Vencob broiler chicks. Chicks were randomly divided into three groups ( $n=25)$, one negative control $\left(\mathrm{T}_{0}\right)$ and two treatments $\left(\mathrm{T}_{1} \& \mathrm{~T}_{2}\right)$. Control group $\left(\mathrm{T}_{0}\right)$ was offered basal diet deficient in natural or synthetic source of amino acids (choline, methionine, lysine \& biotin). Treatment group $\mathrm{T}_{1}$ was fed with basal diet supplemented with polyherbal formulation comprising natural sources (herbs) that mimic the activity of amino acids (choline, methionine, lysine \& biotin) @ $2 \mathrm{Kg}$ /tonne of feed while treatment group $\mathrm{T}_{2}$ was fed with basal diet supplemented with combination of synthetic choline chloride $(600 \mathrm{gm} /$ tonne $)$, synthetic methionine $(1 \mathrm{~kg} / \mathrm{tonne})$, synthetic lysine (1 kg/tonne) and biotin $(150 \mathrm{mg} /$ tonne). Growth \& performance parameters were recorded at weekly intervals and a metabolic trial for nutrient retention studies was conducted at the end of study. A significant increase in mean body weight gain, mean final body weight, feed efficiency \& nutrient retention was observed in both the treated groups as compared to untreated control. The results of group $\mathrm{T}_{1}$ supplemented with herbal sources of amino acids were in confirmation with $\mathrm{T}_{2}$ supplemented with combination of synthetic amino acids suggesting that the polyherbal formula can successfully replace synthetic additives in feed.
\end{abstract}

Keywords: amino acid, broiler, growth, herbal, nutrient, performance

\section{I ntroduction}

Methionine, choline and Lysine are universally recognized as the most two limiting amino acids in broiler diets based on corn and soybean meal (Baker, 1997; Han and Baker, 1991). The supplementation of broiler feeds with these amino acids is very common in the poultry industry. However, Synthetic methionine and choline are metabolized into highly toxic compounds such as methylpropionate, trimethylamine thereby, adversely altering the performance of poultry birds (Bender, 1975). Synthetic methionine and choline are listed among the prohibited synthetic substances and its usage has been questioned in organic farming practices (Fanatico et al., 2007). Feed rations that are high in plant proteins, such as soyabean meal can be used instead of synthetic amino acid supplements, but may lead to environmental pollution. It is difficult to design diet with sufficient Methionine and choline but without oversupplying protein or adding synthetic amino acids in crystalline form.
Alternatively, many herbs are rich source of these essential amino acids and also mimic the activity like that of methionine, choline or biotin. These may be supplemented along with ration to replace synthetic in feed.

The present experimental trial was conducted to evaluate efficacy of polyherbal coded formulation AV/CAP/18 (supplied by M/S Ayurvet Limited, Baddi, India) in comparison to synthetic additives in improving overall growth, productivity and performance in broilers.

\section{Materials and Methods}

An experimental trial was conducted in seventy five day old Vencob broiler chicks of nearly similar live body weight at Department of Animal Nutrition, College of Veterinary and Animal Sciences, Udgir, Dist. Latur, Maharashtra, India. The methodology of research trial and protocol was legally approved by the Committee for the purpose of control and supervision on experiments in animals (CPCSEA) No. 164/2005 (India) and Institutional Ethics Committee, C.V.A.S, 
Comparative efficacy of supplementation of phytoconcentrate herbal preparation and synthetic amino acid

Table-1.1. Feed Formulations of Experimental Groups

\begin{tabular}{|c|c|c|c|c|c|}
\hline \multirow[t]{2}{*}{ Sr. No. } & \multirow[t]{2}{*}{ Feed Ingredient } & \multicolumn{2}{|c|}{ B roiler Starter } & \multicolumn{2}{|c|}{ B roiler Finisher } \\
\hline & & Control T0 & Treatments T1 \& T2 & Control T0 & Treatments T1 \& T2 \\
\hline 1 & Maize & 45.00 & 53.70 & 50.00 & 59.00 \\
\hline 3 & Sun flower Meal & 11.00 & ---- & 05.00 & ----- \\
\hline 4 & Soybean Meal & ----- & 38.00 & ---- & 35.00 \\
\hline 5 & Groundnut Meal & 33.00 & ---- & 33.00 & ---- \\
\hline 8 & Oil & 02.00 & 00 & 02.50 & 02.50 \\
\hline 9 & Salt & 00.50 & 0.5 & 00.50 & 00.50 \\
\hline 10 & Total & 100.00 & 100 & 100.00 & 100.00 \\
\hline
\end{tabular}

Table-1.2. Chemical Composition of Rations of Experimental Groups

\begin{tabular}{|c|c|c|c|c|c|}
\hline \multirow[t]{2}{*}{ Sr. No. } & \multirow[t]{2}{*}{ Feed Ingredient } & \multicolumn{2}{|c|}{ B roiler Starter } & \multicolumn{2}{|c|}{ B roiler Finisher } \\
\hline & & Control T0 & Treatments T1 \& T2 & Control To & Treatments $\mathrm{T} 1 \&$ T2 \\
\hline 1 & Crude Protein (\%) & 23.41 & 22.38 & 21.24 & 21.06 \\
\hline 3 & $\mathrm{C}: \mathrm{P}$ ratio* & $125.37: 1$ & $128.37: 1$ & $136.84: 1$ & $142.64: 1$ \\
\hline 4 & Crude Fibre (\%) & 5.54 & 4.04 & 5.39 & 3.87 \\
\hline 5 & Ether Extract (\%) & 4.87 & 3.72 & 5.27 & 5.31 \\
\hline 8 & Lysine $(\%)^{*}$ & 0.55 & 1.21 & 0.53 & 1.13 \\
\hline 9 & Methionine $(\%)^{*}$ & 0.23 & 0.44 & 0.21 & 0.41 \\
\hline
\end{tabular}

Udgir, Maharashtra, India. Chicks were randomly divided into three groups $(\mathrm{n}=25)$, one negative control $\left(\mathrm{T}_{0}\right)$ and two treatments $\left(\mathrm{T}_{1}\right.$ and $\left.\mathrm{T}_{2}\right)$.

Control group $\left(\mathrm{T}_{0}\right)$ was offered basal diet deficient in natural or synthetic source of amino acids (choline, methionine, lysine and biotin). Treatment group $\mathrm{T}_{1}$ was fed with basal diet supplemented with herbal formulation containing combination of herbs (Cicer arientinum, Phaseolus mungo, Mucuna pruriens, Trigonella foenumgraecum, Nigella sativa, Citrullus colocynthis and many more) that mimic the activity of amino acids (choline, methionine, lysine and biotin) @ $2 \mathrm{Kg} /$ tonne of feed while treatment group $\mathrm{T}_{2}$ was fed with basal diet supplemented with combination of synthetic choline chloride $(600 \mathrm{gm} /$ tonne $)$, synthetic methionine ( $1 \mathrm{~kg} /$ tonne $)$, synthetic lysine (1kg/tonne) and biotin (150mg/tonne).

The chicks of all the three groups were housed separately and maintained on ad libitum broiler starter and finisher ration and clean drinking water throughout the experiment. The chicks were vaccinated for Lasota and IBD vaccines on $7^{\text {th }}$ and $14^{\text {th }}$ day of age, respectively. Individual body weight and feed consumption of broilers from all three groups were measured at weekly intervals from 0-42 days. Mortality of each pen was recorded on a daily basis. A metabolic trial for nutrient retention studies was conducted on representative four birds per group during last week of experiment. Daily feed consumption as well as faecal output from each bird was measured. The daily faecal output was collected and preserved for proximate analysis studies. The feed and fecal samples were subjected for analysis of dry matter (DM), crude protein $(\mathrm{CP})$, crude fibre $(\mathrm{CF})$, ether extract $(\mathrm{EE})$, total ash (TA) and nitrogen free extract (NFE). The nutrient digestibility was calculated after analysis of nutrient content in feed consumed and feces voided by the selected birds. Weende's system of proximate analysis was adopted for estimation of chemical composition of feed and feces in the nutrient analysis. Statistical analysis was carried out by the method given by Snedecor and Cochran, 1980.

\section{Results and Discussion}

Growth and Performance: The feed formula and chemical composition of broiler starter and broiler finisher ration for control group and treatment groups is depicted in Table no.1.1 and 1.2. The \% calculated essential amino acid in control group diet is either lower or completely absent in positive control group dietary formula. Mean body weight gain was recorded to be significantly higher in treatment groups $\left(\mathrm{T}_{1}\right.$ and 
Comparative efficacy of supplementation of phytoconcentrate herbal preparation and synthetic amino acid

Table-2. Mean ( \pm SE) values of Gain in weight at weekly intervals of study

\begin{tabular}{|c|c|c|c|c|c|c|c|}
\hline \multirow[t]{2}{*}{ Parameter } & \multirow[t]{2}{*}{ Group } & \multicolumn{6}{|c|}{ Intervals of study (weeks) } \\
\hline & & 1st & 2nd & 3rd & 4th & 5 th & 6th \\
\hline $\begin{array}{l}\text { Gain in weight } \\
\text { (gm) }\end{array}$ & $\begin{array}{l}\mathrm{T}_{0} \\
\mathrm{~T}_{1} \\
\mathrm{~T}_{2} \\
\text { Stat }\end{array}$ & $\begin{array}{c}22.91^{\mathrm{a}} \pm 0.18 \\
79.55^{\mathrm{b}} \pm 0.34 \\
83.82^{\mathrm{b}} \pm 0.13 \\
s\end{array}$ & $\begin{array}{c}83.13^{\mathrm{a}} \pm 0.36 \\
187.21^{\mathrm{b}} \pm 0.47 \\
192.46^{\mathrm{b}} \pm 0.49 \\
s\end{array}$ & $\begin{array}{c}155.37^{\mathrm{a}} \pm 0.44 \\
454.70^{\mathrm{b}} \pm 0.18 \\
458.79^{\mathrm{b}} \pm 0.36 \\
s\end{array}$ & $\begin{array}{c}113.51^{\mathrm{a}} \pm 0.27 \\
245.10^{\mathrm{b}} \pm 3.92 \\
240.39^{\mathrm{b}} \pm 6.91 \\
\text { HS }\end{array}$ & $\begin{array}{c}237.13^{\mathrm{d}} \pm 0.49 \\
340.85^{\mathrm{b}} \pm 15.49 \\
373.77^{\mathrm{a}} \pm 9.13 \\
H S\end{array}$ & $\begin{array}{c}198.12^{\mathrm{a}} \pm 9.30 \\
432.26^{\mathrm{b}} \pm 17.57 \\
406.62^{\mathrm{b}} \pm 11.65 \\
\mathrm{HS}\end{array}$ \\
\hline
\end{tabular}

Table-3. Mean ( \pm SE) values of Live body weight at weekly intervals of study

\begin{tabular}{|c|c|c|c|c|c|c|c|}
\hline \multirow[t]{2}{*}{ Parameter } & \multirow[t]{2}{*}{ Group } & \multicolumn{6}{|c|}{ Intervals of study (weeks) } \\
\hline & & 1st & 2nd & 3rd & 4th & 5th & 6th \\
\hline $\begin{array}{l}\text { Body weight } \\
\text { (gm) }\end{array}$ & $\begin{array}{l}\mathrm{T}_{0} \\
\mathrm{~T}_{1} \\
\mathrm{~T}_{2} \\
\text { Stat }\end{array}$ & $\begin{array}{c}72.11^{\mathrm{a}} \pm 0.18 \\
128.35^{\mathrm{b}} \pm 0.34 \\
132.12^{\mathrm{b}} \pm 0.13 \\
s\end{array}$ & $\begin{array}{c}155.24^{\mathrm{a}} \pm 0.23 \\
315.56^{\mathrm{b}} \pm 0.23 \\
324.57^{\mathrm{b}} \pm 0.43 \\
s\end{array}$ & $\begin{array}{c}310.60^{\mathrm{a}} \pm 0.31 \\
770.26^{\mathrm{b}} \pm 0.24 \\
783.36^{\mathrm{a}} \pm 0.44 \\
\mathrm{~s}\end{array}$ & $\begin{array}{c}424.12^{\mathrm{a}} \pm 0.28 \\
1015.36^{\mathrm{b}} \pm 3.56 \\
1023.75^{\mathrm{b}} \pm 6.48 \\
H S\end{array}$ & $\begin{array}{c}661.24^{\mathrm{a}} \pm 0.36 \\
1356.21^{\mathrm{b}} \pm 16.51 \\
1397.52^{\mathrm{b}} \pm 4.81 \\
\mathrm{HS}\end{array}$ & $\begin{array}{c}859.36^{\mathrm{e}} \pm 9.31 \\
1788.47^{\mathrm{b}} \pm 10.70 \\
1804.14^{\mathrm{b}} \pm 10.70 \\
\text { HS }\end{array}$ \\
\hline
\end{tabular}

Table-4. Mean (+ SE) values of Digestibility Coefficient (\%) of Various Nutrients of experimental Birds at weekly intervals of study

\begin{tabular}{lcccccc}
\hline Group & \multicolumn{5}{c}{ Digestibility Coefficient (\%) of Nutrients } \\
\cline { 2 - 6 } & DM & CP & CF & EE & Ash & NFE \\
\hline $\mathrm{T}_{0}$ & $69.08^{\mathrm{a}} \pm 0.31$ & $68.78^{\mathrm{a}} \pm 0.25$ & $62.89^{\mathrm{a}} \pm 0.13$ & $61.51^{\mathrm{a}} \pm 0.10$ & $52.07^{\mathrm{a}} \pm 0.22$ & $65.78^{\mathrm{a}} \pm 0.20$ \\
$\mathrm{~T}_{1}$ & $74.00^{\mathrm{b}} \pm 0.36$ & $81.48^{\mathrm{b}} \pm 0.11$ & $63.63^{\mathrm{ab}} \pm 0.11$ & $74.17^{\mathrm{b}} \pm 0.14$ & $54.98^{\mathrm{b}} \pm 0.27$ & $67.75^{\mathrm{b}} \pm 0.24$ \\
$\mathrm{~T}_{2}$ & $77.86^{\mathrm{b}} \pm 0.25$ & $82.04^{\mathrm{b}} \pm 0.55$ & $64.34^{\mathrm{b}} \pm 0.69$ & $77.62^{\mathrm{b}} \pm 0.44$ & $60.62^{\mathrm{b}} \pm 0.24$ & $73.91^{\mathrm{b}} \pm 0.04$ \\
$\mathrm{~S}_{\text {tat }}$ & $\mathrm{S}$ & $\mathrm{S}$ & $\mathrm{S}$ & $\mathrm{S}$ & $\mathrm{S}$ & $\mathrm{S}$ \\
\hline
\end{tabular}

Means bearing at least one common superscripts within rows do not differ significantly.

HS- Highly significant $(P<0.05)$, NS- Non significant, $S$ - Significant

T2) than control from 1st to 6th week of experiment, however, the values were non-significantly different among two treatments from 1st to IIIrd week (Table 2). At VIth week, the mean body weight gain of $\mathrm{T}_{1}$ group was significantly higher than $\mathrm{T}_{2}$ suggesting that the supplementation of herbal product lead to comparatively higher body weight gain than the group fed combination of synthetic amino acids in basal ration. The mean final body weight at the end of 6th week in treatment groups $\mathrm{T}_{2}(1804.1410 .70 \mathrm{gm})$ and $\mathrm{T}_{1}$ (1788.47 $10.70 \mathrm{gm}$ ) was significantly higher than the positive control group $\mathrm{T}_{0}(859.369 .31 \mathrm{gm})$ (Table 3$)$.

The depression in body weight gain and mean final body weight in positive control group $\mathrm{T}_{0}$ may be correlated with the basal diet deficient in essential amino acids methionine, choline, lysine and biotin. In poultry ration, along with the vitamins and minerals, proteins play a critical role, amongst these methionine and lysine are essentially required for overall growth and performance (Swick et al., 1990). Herbs namely Cicer arientinum, Phaseolus mungo, Mucuna pruriens are rich source of proteins and essential amino acids (Baker, 1997). The significant increase in mean final body weight and body weight gain in treatments may be attributed to the supplementation of essential amino acids in basal ration. Addition of methionine over and above the recommended requirement of broilers improves their performance in terms of body weight gain and food conversion efficiency (Ohta and Ishibashi, 1995).

The results in the present study are in corroboration with those reported by Kalbande et al., (2009) that addition of herbal source of methionine along with feed improved performance in terms of body weight gain and feed efficiency in broilers. Similar results were also given by Simone et al., (1995) and Ohta and Ishibashi, (1995) that supplementing herbal or synthetic sources of essential amino acids improved feed to gain ratio in broilers.

The feed conversion ratio for $\mathrm{T}_{0}$ (1.88) was significantly higher than $\mathrm{T}_{1}(1.544)$ and $\mathrm{T}_{2}(1.536)$ that might be due to improved feed efficiency due to supplementation of either herbal sources or synthetic amino acids in feed. The results are well in confirmation with those reported by Ozturkan et al., (1993) that supplementation of choline, methionine and lysine to broilers improved performance in terms of feed efficiency and livability.

Nutrient Retention Studies: The mean values of digestibility coefficients of various nutrients of different groups are summarized in Table-4. The digestibility coefficient of DM and CP revealed non- 
significant difference among $\mathrm{T}_{1}$ and $\mathrm{T}_{2}$; however, it was significantly higher in treatments than control group $\mathrm{T}_{0}$. Similar results have been recorded for $\mathrm{EE}$ and NFE (table-4). The improvement in the digestibility coefficients in treatments groups supplemented either with herbal source of amino acids or synthetic amino acid supplemented group in comparision to the control group fed deficient diet suggests the positive role of essential amino acids in improving nutrient retention. The results are in confirmation with those reported by Babutunde et al., (1976).

\section{Conclusion}

Results of the present investigation demonstrate significant improvement in growth and performance parameters and feed utilization in treatment groups, it can be inferred that supplementing either synthetic or herbal sources of amino acids in broiler ration improves overall growth, performance, feed efficiency and nutrient retention and utilization in broilers and the herbal formula can successfully replace synthetic additives in feed.

\section{Acknowledgements}

The authors are thankful to Dean, College of Veterinary and Animal Sciences, Udgir, Maharashtra, for infrastructure facilities and Ayurvet Limited, for providing samples to conduct the research.

\section{References}

1. Babatunde; B., Fetuga, L. and Kassim, E. (1976). Methionine supplementation of low protein diets for broiler chicks in the tropics. British Poultry Science, 17, (5): 463-469.

2. Baker, D.H., (1997). Ideal amino acid profiles for swine and poultry and their application in feed formulation. Biokyowa Technical Review 9:1-24.

3. Fanatico, A.C., Owens, C.M. and Emmert, J. L. (2007) Organic poultry Production in the U.S.: broilers. Journal of Applied Poultry Research, 18(2): 355-366.

4. Han, Y. and Baker, D.H. (1991). Lysine requirements of fast and slow growing broiler chicks. Poultry Science, 70(10): 2108-2114.

5. Kalbande, V.H., Ravikanth, K., Maini S. and Rekhe, D.S. (2009). Methionine Supplementation Options in Poultry. International Journal of Poultry Science, 8 (6): 588-591.

6. Ohta, Y. and Ishibashi, T. (1995). Effects of dietary glycine on reduced performance by deficient and excessive methionine in broilers. Japanese Poultry Science, 31: 81-89.

7. Ozturkan, O., Demise, E. and Gorgulu, M. (1993). The effect of supplementary methionine, choline and lysine on the performance and the amount of abdominal fat in broiler chickens. Poultry Abstract, 21: 195.

8. Simone, A., Bergner, H. and Buivan, D. (1995) Methodological investigation on the metabolism oriented determination of methionine requirement of broiler chickens. 3. Degradation of 14c-(CH3)-and 35-Smethionine after feeding of synthetic diets. Archive of Animal Nutrition, 47: 229-244.

9. Snedecor, G.W. and Cochran, W.G. (1980). Statistical Methods. $7^{\text {th }}$ Ed. The Iowa State University Press, Iowa.

10. Swick, R.A., Creswell, D.C., J.J. and Ivey, F.J. (1990) Impact of methionine sources on performance of broilers growing under warm and humid conditions [abstracts]. Poultry Science, 69: 194. 